し一方，近年次々と報告されている胸椎部脊髄症のう ちで，好発部位より見れば，極めて可動性の少ない中 部胸椎に多発する疾患もあるが, 黄色靭帯骨化, 春椎 症, 椎間板へルニア等, 大半の疾患は, 下部胸椎に集 中している. 今回我々は，乙れらの局所的発生因子と して理動負荷域の差を求めた，確かに，下部胸椎に大 きな可動性（特に第 11-12 椎間では第 4-5-6 椎 間の約 $3 \sim 5$ 倍）を認め，更に後等より前彎への移行 部という生理的彎曲とも相まって，ストレスが加わり 易く，加うるに，乙の部では栄賸血管に乏しいことか らも，くり返される minor trauma が，一つの発生 要因となるととが推察される．また加令による変化 あ, 形椎, 腰椎におけると同様，40 代よりやや顕著 に可動性が減少し退行性変化の進行することが確認さ れた.

$$
\text { 文献 }
$$

1）上妻隆治; 脊柱の形状と運動性に就て, 医学研 究. $28: 463,1958$.

2) Bakke, S. N.; Röntogenologische Beobachtungen U̇ber di Bewegungen der Wirbelsăule. Acta Radiol. Suppl. 13; 1931.
3) Dittmar, O.; Röntgenstudien der Mechanologie der Wirbelsäle. Z. Orthop. Chir. $55 ; 321,1931$.

4）長谷川春雄：成人婹仙椎部可動性の「レ」綝学的 研筑 (第 1 報)。目整会誌. $31 ; 51 ， 1957$.

5）伊藤三郎：脊椎角度計に上万成人脊椎彎曲度並 びに可動城の研究. 災害医学会会誌. 5; 96, 1958.

6)国武博紀：曲線定規に上る脊椎運動性の観察. 久留米医学㵶誌. $22 ; 1566,1959$.

7) 松股㹂：脊柱の計涮学的研究，医学研究. 27 ; 108, 1957.

8）西辻知生：颗㕆腕症候群患者の頚推レ綝学的研 究. 中部整災誌. $6 ; 890,1963$.

9) 弓立恒善: 胸椎運動の分析. 四国医学雑誌。 $23 ; 10,1967$.

算問 九大整形 角田 信昭
姿勢との関係で何か差はありませんでしたか。

解 答出口大 加藤 勇満

確かに姿勢により運動範囲は異なるようであるが今 回はすべて仰卧位および側臥位での測定値である.

\title{
長管骨々幹端部の走査電顕像
}

\author{
鳥取大学整形外科 \\ 伊達和友・豊島良太 \\ 山本吉蔵・前山厳

\section{Scanning Electron Microscopic Observation of the Metaphysis of the Long Bone} \\ By \\ K. Date, R. Teshima, K. Yamamoto \\ and I. Maeyama \\ Department of Orthopedic Surgery, Tottori \\ University School of Medicine
}

Endochondral bone formation is one of the characteristic features of the primary spongiosa. Using the metaphysis of the long bone of two-week-old normal Wistar rat, we observed three-dimensional ultrastructures of collagen fibers between the calcified cartilage matrix and osteoblasts under the field emission scanning electron microscope.

Approaching the diaphysis, the bundles of collagen fibers which osteoblasts lay down on the calcified cartilage matrix increased in width. 
Cytoplasmic processes of osteoblasts extended between collagen fibers, which were relatively distinctly bordered by the calcified cartilage matrix, and their direction was nearly parallel to the axis of the calcified cartilage matrix.

\section{はじめに}

Metaphysis の primary spongiosa において, 特徴的な所見の 1 つは, 石死化軟骨基質表面への骨添 加, 即ち endochondral bone formation である. 今回, この endochodral bone formation につい て，その立体的微細構造を観察するために field emission 型走查電子顕微鏡を用いてこれを行なっ た.

\section{観察材料及び方法}

材料は生後 2 週目の正常 Wistar 系ラットの脛骨 近位骨幹端部を使用した，採取した試料は，2.5\%グ ルタールアルデヒド（0.1 M リン酸緩衝液）で固定 し, 次いでェタノール系列で脱水後, 液体窒素にて凍 結, 矢状方向に割断を行なった. その後臨界点乾燥を 行ない, 試料の割断面に金 sputtering 蒸着を行な い, field e mission 型走査電子顕微鏡にて観察した. また試料の一部は, 細胞内構造をより明確にするため に ion etching を施し, 同様に金 sputtering 蒸着 後観察した.

\section{観 察 結 果}

骨端成長軟骨帯より骨幹端への移行部では, 変性し た軟骨細胞を示す泡状細胞が見られ，その細胞間縦走 基質より連続している石兏化軟骨基質は，光顕で見ら れるように, primary spongiosa に向って 鐘乳石 状に伸びて存在していた，骨端成長軟骨最下の横走隔 壁に接して毛細血管は豊富に認められたが，明らかに 骨芽細胞と思われる細胞群は少なかった（図 1 ).

最下の骨端成長軟骨横走隔壁直下より，約 100 $150 \mu \mathrm{m}$ 離れた石灰化軟骨基質表面上に，はじめて成 熟した collagen fiber が薄く膜状に添加しているの が見られた（図 2 矢印）。

石灰化軟骨基質表面に形成された collagen fiber の層の幅は部位によって多少差があるが，このレベル では非常に薄いために拡大像によって，その存在が確 認された（図 3 ).

Collagen fiber の層は主に骨芽細胞と石灰化軟骨

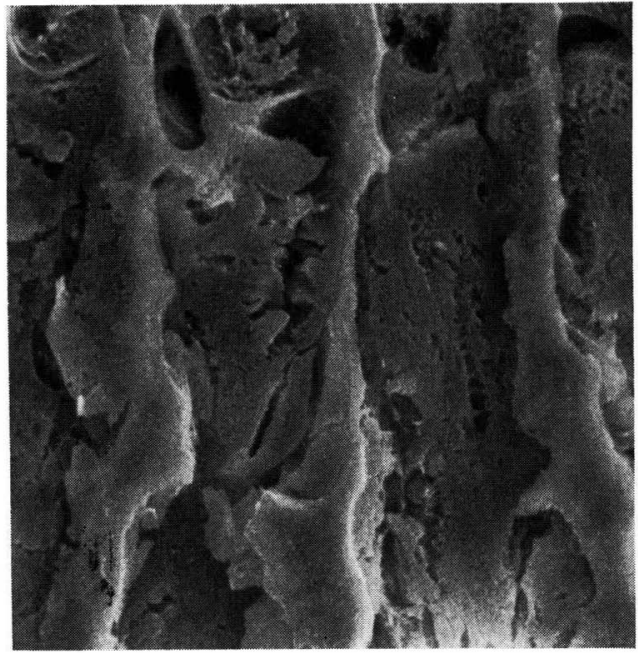

図1鐘乳石状に伸びている石灰化軟骨基質 $\times 470$

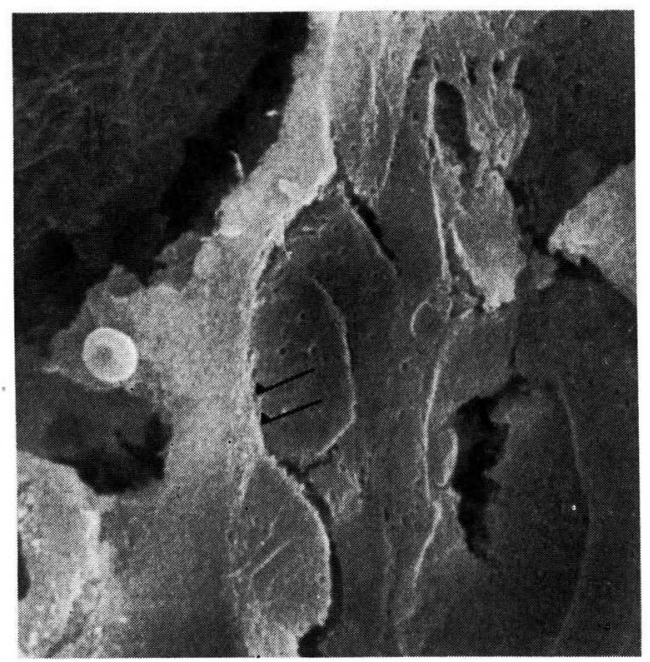

図 2 石灰化軟骨基質表面に添加された collagen fiber $\times 880$

基質の間に存在していた，骨芽細胞の大きさは，その 長軸が $20 \mu \mathrm{m}$ 前後で 卵円形を 呈しており, 石灰化軟 骨基質に沿って連らなって存在していた（図 2).

細胞内構造を明確にするために，割断面に ion etching を施した試料で観察すると，骨芽細胞には 比較的大型の球形をなす核が細胞質の 1 側に偏在して 


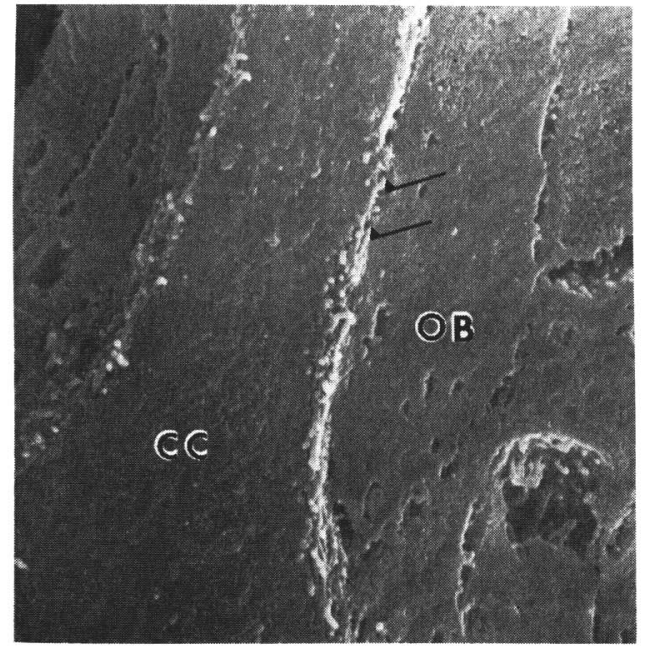

図 3 O B : 骨芽細胞

C C : 石灰化軟骨基質 $\times 4900$

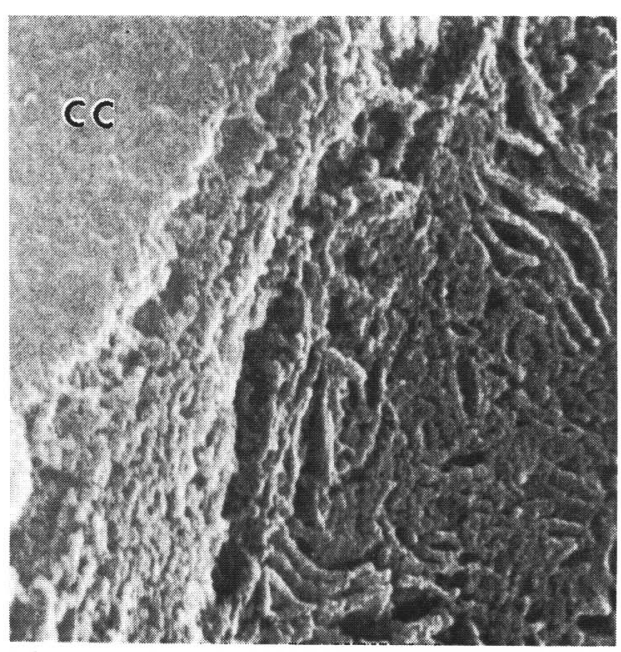

図4 骨芽細胞 $\times 9180$

いた，その核の周囲には，豊富な粗面小胞体が層をな して密に存在していた．また collagen fiber の層は ion etching 効果のためか，その配列は不明瞭とな っていた（図4).

更に diaphysis 側に下った部分では，石灰化軟骨 基質と骨芽細胞の間には，約 $1.0 \sim 2.5 \mu \mathrm{m}$ 幅の collagen fiber の層が存在していた. このように, collagen fiber の層の幅は, 骨端成長軟骨帯から離 れるにつれて，次第にその厚さを増していた，一方骨 芽細胞は, collagen fiber の層の中に 細胞質突起を

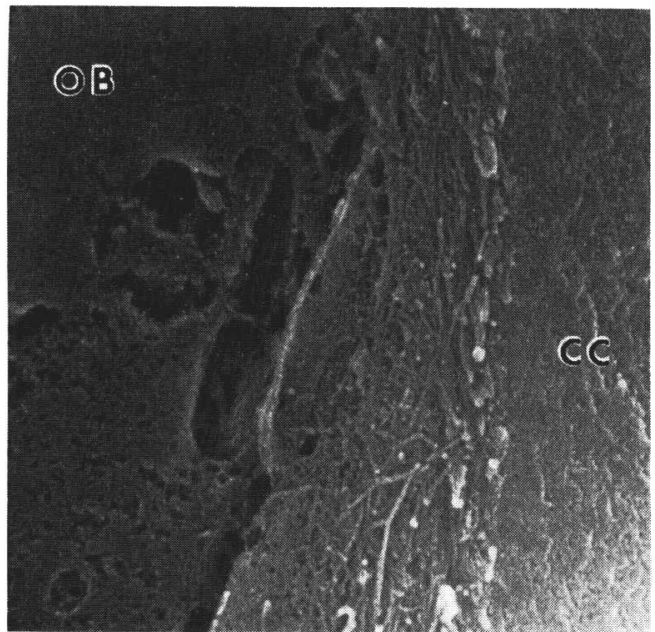

図 5 collagen fiber の層の中に伸びた 骨芽細胞の細胞質突起 $\times 8860$

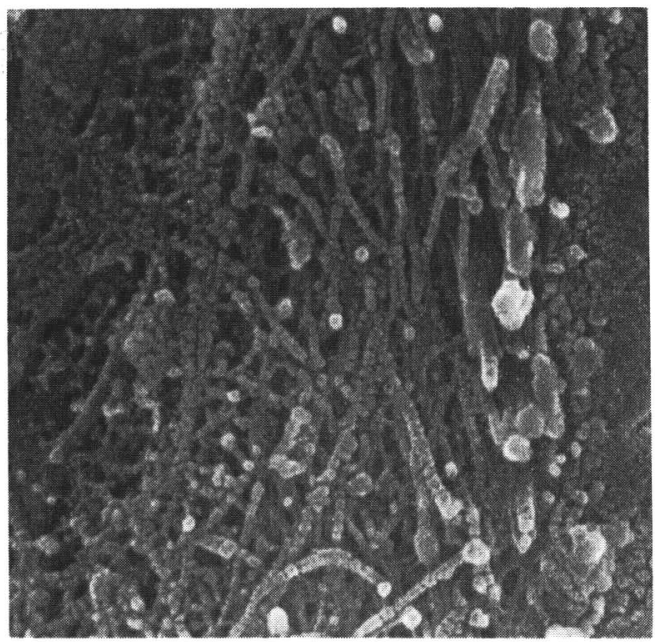

図 $6 \times 27700$

伸ばしているが，突起の部分と collagen fiber との 相互関係は明らかではなかった（図 5 ).

石灰化軟骨基質之骨芽細胞の間を更に拡大すると, collagen fiber の各線維は明瞭に観察された。一様 に充実性を呈す石灰化軟骨基質と collagen fiber の 層との境界は, 比較的明瞭であった. collagen fiber の配列は疎であり，その方向は一部錯綜するものも見 られるが，ほぼ石灰化軟骨基質と平行しており，各線 維には約 $600 \AA ̊$ の周期性が観察された（図6). 


\section{まと め}

てれまで生物組織の微細構造については，光顕およ び透過型電影を用いて平面的な観察が行なわれてきた が, 走查電影の試料技術の進歩により, 細胞・基質の 立体的観察が可能となった. そこで, primary spongiosa における石灰化软骨基兵表面への成熟した collagen fiber $の$ 形成, 即ち endochodral bone formation の立体的微細構造を研究する目的で, field e mission 型走査䉓子影微鏡を用いて，とれを行なっ た.

成熱した collagen fiber の層が primary spongiosa に残存する石灰化㳄骨基質表面に，はじめて見 られたのは, 骨端成長軟骨帯の最下の横走隔壁直下か ら, 約 $100 \sim 150 \mu \mathrm{m}$ 教れたレベルであった. さらに diaphysis 僛に下ると, 石灰化㳄骨基質上の collagen fiber の層の幅は次第に增加しており，各線維の走向 も石灰化軟骨基質と平行になってゅく傾向にあった. collagen fiber の層は主に骨芽細胞之石灰化軟骨基 質との間に見られ，石死化㳄骨基質との境界は比較的
明瞭であった. しかし，成熟した collagen fiber と 石灰化軟骨基質との明確な関連性の有無については明 らかにすることができず，今後の課題と考えている. 一方, 骨芽細胞が collagen fiber を形成するという 事は周知であり, 今回の钼察でも骨芽細胞の細胞突起 が, collagen fiber の層の間に伸びている像が見ら れた.

\section{考文 献}

1) Bloom, W. and Fawcet, D. W.: A Textbook of Histology, 10th ed. Saunders, Philadelphia, 1975.

2) Ham, A. W.: Histology, 7th ed. Lippincott, Philadelphia, 1975.

3) Loë, H.: Acta Odont. Scand. $17: 311-427$, 1959.

4) Robinson, R. A. and Cameron, D. A.: J. Biophysic, and Biochem. Cytolo, vol. 2, no. 4, suppl. 1956.

5) Robinson, R. A. and Cameron, D. A.: J. Bone and Joint Surg. 40-A : 678-697, 1956.

6)田中：臨床検查. $20: 481-488,1976$.

7）莗島・注加：日整会誌。49：647，1975.

\title{
両側に発生した先天性下腿彎曲症の 1 例
}

(いわゆる先天性脛骨偽関節)

九州大学整形外科学教室
安
千恵子・森 久 喜八郎
豊 永 敏 宏・松 永 $大$ 助

A Case Report of so-called Pseudarthrosis of the Bilateral Tibiae

By

\author{
C. Ann, K. Morihisa, T. Toyonaga \\ and D. Matsunaga \\ Department of Orthopaedic Surgery, Faculty \\ of Medicine, Kyushu University
}

So-called pseudarthrosis of the tibia is one of rare diseases. Only 26 cases were seen in our clinic during 50 years (1926-1976), and they were all uni-lateral cases.

The following case is reported because it demonstrates both congenital bowing of the bilateral legs. 